American Journal of Applied Sciences 7 (4): 590-596, 2010

ISSN 1546-9239

(c) 2010Science Publications

\title{
Trade Relationship Between Oman and Its Major Trading Asian Partners
}

\author{
Abdusalam F. Yahia \\ Department of Economics, Faculty of Economics and Commerce, \\ University of Al-Margibe-Al-Khumis, Libya
}

\begin{abstract}
Problem statement: No empirical research exists that examines the interdependence of trade between Oman and its five major trading Asian partners (Emirates, Japan, South-Korea, Thailand and Mainland China). This study attempted to fill this gap in the literature by examining the interaction of trade between Oman and its major trading Asian partner. Particularly, this study attempted to answer the very important question that is there any feedback effect of the trade relationship between Oman and its major trading Asian partners. Approach: A simultaneous-equations model with a double-log form was developed and tested in this study in order to achieve its objectives. Results: The model was estimated using the Two Stage Least Square (2SLS) procedure of estimation and the main findings of the analysis revealed that the price of oil does not seem to be the major determinant of Omani exports to its major trading partners with exception of Japan. The short-term elasticity of Omani imports from its major trading partners with respect to its income seems to be higher (e.g., ranging from 0.55-2.0) in all cases. Conclusion: This study brought new empirical evidence on the trade interdependence and suggested that there is a significant impact (a feedback effect) on the level of GDP of Omani's four major trading partners namely Emirates, Japan and South Korea. Therefore, policy maker in sultanate of Oman should be aware of such interdependence and consider the degree of feedback effect of trade in any economic programming that linked and related to these countries.
\end{abstract}

Key words: Trade relationship, feedback effect, oil prices, Sultanate of Oman

\section{INTRODUCTION}

The Oman economy is a developing small open economy in the Middle East with notable oil and gas resources and a considerable trade surplus. Indeed, foreign trade plays an essential role in determining Omani economic growth. The impact of foreign trade on the Omani economy can be explained through the mechanism of trade interdependence as follows: (i) an increase in Omani exports from its trading partners will increase its income, which in turn leads imports to rise. (ii) Oman's exports to its trading partners are officially determined by oil prices and the income of its trading partner. It is assumed that the downturn in oil prices will negatively affect Oman's exports to its trading partners, which result in a decrease of Omani income from its trading partners. (iii) The GDP of trading partners of Oman is a function of its exports to Oman (Omani imports) and to the rest of the world. Therefore, the raise in Omani imports will increase the income of its trading partners, which in turn results in an increase in their imports (Omani exports) from Oman. This is the feedback effect.

The aim of this study is to investigate the interaction of international trade and the degree of feedback effects between Oman and its major trading partners. This investigation will be based on the exportled growth hypothesis within the framework of international trade interdependence Thirlwall (1986). Hence, the structure and magnitude of trade between Oman and its five major trading Asian partners (Emirates, Japan, South-Korea, Thailand and Mainland China) during the period 1980-2006 will be tested in this study.

A brief review of the literature: The literature on feedback effects of foreign trade has intensified during the past two decades (Metwally and Vadlamudi, 1992; Ardakani, 1996; Rammadhan, 2000; Yahia and Metwally, 2007). Metwally and Vadlamudi (1992) developed a simultaneous equation model in order to test if there is a feedback effect of the trade relationship between Oman and Middle-Eastern countries during the period between 1971 and 1988. Their model consists of seven endogenous and four exogenous variables. The regression results of their model show that there is no feedback effect between Oman and these countries. This could be explained by the fact that the participation of Middle Eastern countries in Omani market is very small. 
Based on the hypothesis that "exports lead to growth" Ardakani (1996) used the simultaneous equations model in order to evaluate trade relationship between Iran and its major trading partners. The empirical results show that Iranian GDP has been significantly affected by the exports of its main trading partners. Further, it confirms that Iranian oil revenue has been essentially influenced by the changes in oil prices. Moreover, he found evidence that exports have positive and extend impact on the rest of the economy.

Rammadhan (2000) examined the feedback impacts in GCC countries with its trading countries over the period from 1970-1996. The author applied the simultaneous equation model in order to evaluate the process of interaction between GCC and the rest of the world. The key findings of this study indicate that there is a significant feedback impact in GCC trade with its major trading partners namely the USA, the EU and Japan.

In 2001 the trade relationships between the GCC and the EU investigated by Metwally and Tamaschke (2001). They developed a simultaneous equations model in order to test for feedback impacts. The results of their study indicated that GCC exports have been significantly affected by the fluctuation in oil prices. It also, confirmed that significant feedback between GCC Countries and EU countries is significant.

The direction of trade of Sultanate Oman: The magnitude of Omani trade with its five major trading Asian partners during the last seven years of this study is illustrated by Fig. 1 and 2. Figure 1 indicates that Oman exports mostly to Asian Countries. For example, approximately $55 \%$ of Omani exports were absorbed by 5 of these countries (Japan, Emirates, China, South Korea and Thailand). A glance at Fig. 2 shows that over $70 \%$ of Omani imports were supplied by only five of its major trading partners (Japan, Emirates, China, South Korea and Thailand). Individually, the data in these pie charts seem to suggest that the largest importer of Omani goods are the Emirates (30\%) followed by Japan (18\%) in the last 7 years of this study. In the conclusion, the above information suggests the existence of trade interdependence between Oman and its major trading Asian partners.

meantime, China is the largest exporter to Oman (22\%) followed by South Korea (18\%).Therefore, this study attempts to extend the recent literature by empirically investigating this interaction and testing if there are any feedback effects.

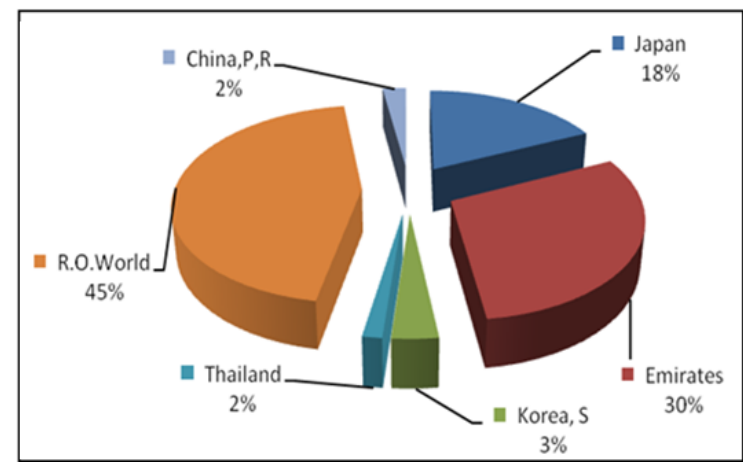

Fig. 1: Oman exports to its Major Trading Asian Partners (Average 2000-2006)*

Note: The criterion is that any country trades with Oman more than $10 \%$ is defined as major trading partner. Source: Plotted by the author and based on data from IMF and AMF databases

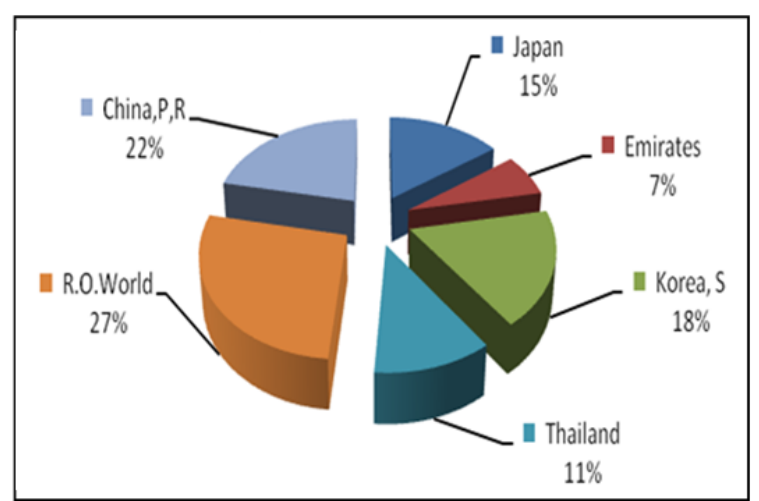

Fig. 2: Oman imports from its Major Trading Asian Partners (Average 2000-2006)*

Note: The criterion is that any country trades with Oman more than $10 \%$ is defined as major trading partner. Source: Plotted by the author and based on data from IMF and AMF databases

\section{MATERIALS AND METHODS}

Data and the method of estimation: Drawing upon the existing literature and following the Metwally et al. (2009), procedure, we develop and specify the following simultaneous equation model that allows us to identify the interaction of trade relationships between Oman and its major trading Asian partners and to test if there are any feedback effects. 
Am. J. Applied Sci., 7 (4): 590-596, 2010

Table 1: The structure of simultaneous-equations model

\begin{tabular}{|c|c|}
\hline Equation number & \\
\hline 1 & $\operatorname{lnYO}_{, \mathrm{t}}=\alpha_{0}+\alpha_{1} \ln \mathrm{XO}_{\text {-partner i.t }}+\alpha_{2} \ln \mathrm{XO} \mathrm{O}_{0, \mathrm{t}}+\alpha_{3} \ln \mathrm{YO}_{, \mathrm{t}-1}+\varepsilon_{1 \mathrm{t}}$ \\
\hline 2 & $\operatorname{lnX} \mathrm{O}_{\text {partner i,t }}=\beta_{0}+\beta_{1} \ln \mathrm{Po}_{\mathrm{t},}+\beta_{2} \ln \mathrm{Y}_{\text {partner i,t }}+\beta_{3} \ln \mathrm{XO} \mathrm{p}_{\text {partner i,t-1 }}+\varepsilon_{2 \mathrm{t}}$ \\
\hline 3 & $\ln \mathrm{Y}_{\text {partner i,t }}=\lambda_{0}+\lambda_{1} \ln \mathrm{X}_{\text {partner i } 0, \mathrm{t}}+\lambda_{2} \operatorname{lnOM} \mathrm{M}_{\text {partner i,t }}+\lambda_{3} \ln \mathrm{Y}_{\text {partner i,t-1 }}+\varepsilon_{3 \mathrm{t}}$ \\
\hline 4 & 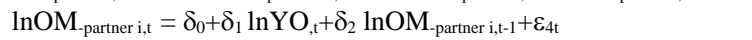 \\
\hline
\end{tabular}

The first equation in Table 1 represents the traditional relationship between GDP and exports. It is assumed that Oman GDP is a function of Omani exports to its major trading Asian partner and as well as to the rest of the world. In equation 2, we hypothesize that Omani exports to its major trading Asian partner is a function of (i) oil prices (ii) income of its major trading Asian partner and (iii) the lagged dependent variable of Omani exports to its partner. It is assumed that, an increase in income of its partner will cause an increase in its imports from Oman. It also expected that the coefficient $\left(\beta_{1}\right)$ will carry a positive sign and the coefficient $\left(\beta_{3}\right)$ of lagged variable $\mathrm{XO}_{\text {partner }}$ will be ranged from zero to one.

In the Eq. 3, we examine the feedback effect between Omani economy and each of its ith major trading Asian partners. It is expected that income of each trading partner depends on its exports to Oman and to the rest of the world. This equation gives us an idea about the mechanism of trade interdependence or the feedback effects. If the coefficient $\left(\lambda_{2}\right)$ is statistically significant, then, it is safe to conclude that, there is a feedback effect between Oman and its major trading Asian partner Metwally et al. (2009).

Equation 4 completes the logic of the model that Omani imports from its trading partner depend on the level of its GDP and the lagged dependent variable.

In each case the dependent variable is regressed against past values of itself and of other variables. The lagged dependent variable gives the equations a dynamic character, allowing for partial adjustment (or lagged effects) (Griffiths et al., 1993; Studenmund, 2000; Gujarati, 2003).

The most crucial problem that arises from using simultaneous equation model is the identification problem because of the difficulties of computing the values of the parameters in the reduced form of the equations (Griffiths et al., 1993; Pindyck and Rubinfeld, 1998) show that the criterion of the order and rank condition is satisfied if and only if, the number of excluded exogenous variables from particular equation in the model is greater than the number of endogenous variables included in that equation minus one. Implementing the order and the rank condition of Therefore, Two Stage Least Squares (2SLS) is the proper method in estimating the four equations of the model Salvatore and Reagle (2002).

\section{RESULTS AND DISCUSSION}

This study uses data covering the period from 1980-2006, which was obtained from the AMF Database; the IMF, the Direction of Trade Statistics Yearbook and the UN database to analyze the trade interaction between Oman and its major trading Asian partners and to test the feedback effects. Eviews program was used to carry out the estimations of all equations in the model.

The computer output of the equations in the model for the five major trading Asian partners is illustrated in Table 2-6. As shown in Table 2-6, the four equations are appropriate, as evident from the values of adjusted $\overline{\mathrm{R}}^{2}$ and the "t" statistics (shown under each coefficient). However, during the period 1980-2006 the Durbin Watson (DW) statistic does not show any significant problem of serial correlation at the five per cent level of significance. Over all, the model is suitable as evident by the fact that the $\mathrm{F}$ test and the coefficients of the lagged variables lies between zero and one in all cases (Studenmund, 2000; Gujarati, 2003).

The regression results for the Emirates are given in Table 2. As can be seen from the first equation, Omani income is strongly influenced by Omani oil exports to the Emirates and to the rest of the world. The " $\mathrm{t}$ " value of the coefficient of the variable " $\mathrm{X}_{\mathrm{O}-\text { Emirates,i,t, }}$, which represents Omani exports to Emirates, is significant at the $5 \%$ level of significance. Examination of the coefficient $\alpha_{3}$ (lagged Omani GDP variable) suggests the existence of a partial adjustment mechanism in this equation.

The results of the second equation suggest that Omani exports to the Emirates are affected by the level of Emirates GDP. The Emirates income is a major determinant of Omani exports to that country. A rise in Emirates income by US\$1 results in an increase in Omani exports to Emirates by approximately US\$ 1.87. However, Omani exports to the Emirates do not seem to be affected by the fluctuation in oil prices. 
This might be explained by the fact that the Omani economy is linked with the Emirates economy by several trade agreements.

The coefficient $\lambda_{2}$ in the Emirates GDP function is statistically significant in which suggests the existence of feedback effects. This is evident from the fact that the value of Omani imports from the Emirates represents a very large proportion of total Emirates exports (Fig. 1 and 2).

The regression results in the fourth equation suggest that Omani imports from the Emirates are positively correlated with its GDP. The marginal propensity of Omani imports from the Emirates is approximately 0.38 in the short-run and 0.97 in the long term. This suggests that an increase in Omani income by US $\$ 1$ results in an increase in Omani imports from Emirates by 38 US Cents in the short term and by approximately 97 US Cents in the long term.

The estimated coefficient $\delta_{1}$ represents the shortterm elasticity, while the long-term elasticity is given by $\delta_{1} /\left[1-\delta_{2}\right]$ (Yahia and Metwally, 2007; Ramanathan, 1998). The short-term elasticity of Omani imports from the Emirates with respect to Omani income is approximately 0.53, while its long-run elasticity is approximately 1.35 . This suggests that an increase in Omani income by $1 \%$ results in an increase in Omani imports from Emirates by approximately 53\% in the short term and by $135 \%$ in the long term.

Data in Table 3 shows the regression results for Japan. These results indicate that Omani income is strongly influenced by Omani oil exports to Japan and to the rest of the world. The " $t$ " value of the coefficient of the variable " $\mathrm{X}_{\mathrm{O}-\mathrm{Japan}, \mathrm{it}}$ ", which represents Omani exports to Japan, is significant at the $5 \%$ level of significance. Further, assessment of the coefficient $\left(\mathrm{Y}_{\mathrm{O}, \mathrm{t}-1}\right)$ suggests the existence of a significant spread effects.

The results of the second equation suggest that the price of oil is a major determinant of Omani exports to that Japan. A rise in oil price by US\$1 results in an increase in Omani exports to Japan by approximately 40 US cent. The coefficient $\lambda_{2}$ in the Japan GDP function is statistically significant, which suggests the existence of feedback effects. This is evident from the fact that the value of Omani imports from Japan represents a very large proportion of Japan's total exports (Fig. 1 and 2).

The regression results in the fourth equation suggest that Omani imports from Japan are positively dependent on GDP within a partial adjustment mechanism. The marginal propensity of Omani imports from Japan is approximately 0.37 in the short term and 0.64 in the long term. This suggests that an increase in Omani income by US\$1 results in an increase in Omani imports from Japan by 0.37 US Cents in the short term and by approximately 64 US Cents in the long term.
The short-term elasticity of Omani imports from Japan with respect to Omani income is approximately 0.55, while its long-term counterpart is approximately 0.93. This suggests that an increase in Omani income by $1 \%$ results in an increase in Omani imports from Japan by approximately 55\% in the short term and by $93 \%$ in the long term.

The regression results for South Korea (SK) are given in Table 4. These results suggest Omani income is strongly influenced by Omani oil exports to South Korea and to the rest of the world. The "t" value of the coefficient of the variable " $\mathrm{X}_{\mathrm{O}-\mathrm{S} . \mathrm{K} \text {,i }}$ ", which represents Omani exports to South Korea, is significant at the 5\% level of significance. In addition, the coefficient $\left(\mathrm{Y}_{\mathrm{O}, \mathrm{t}-1}\right)$ suggests the existence of a significant spread effects.

The results of the second equation suggest that the lagged $\mathrm{X}_{\mathrm{O}}$ variable is the key determinant of Omani exports to South Korea, while the price of oil does not have any significant impact on Omani exports to the South Korea, The coefficient $\lambda_{2}$ in the South Korea, GDP function is statistically significant, which suggests the existence of feedback effects.

This is evident from the fact that the value of Omani imports from SK, represents a large proportion of total SK, exports (Fig. 1 and 2). Although, the coefficient $\lambda_{1}$ in the SK, GDP function is statistically significant at $5 \%$ level, which suggests that the SK, exports to the countries other than Oman is also another key determinant of the South Korean GDP.

The regression results in the fourth equation suggest that Omani imports from SK, are positively related to the Omani GDP within a partial adjustment mechanism. The marginal propensity of Omani imports from SK, is approximately 0.67 in the short term and 0.97 in the long term. This suggests that an increase in Omani income by US\$1 results in an increase in Omani imports from SK, by 0.67 US Cents in the short term and by approximately 97 US Cents in the long term.

The short-term elasticity of Omani imports from SK, with respect to Omani income is approximately 1.57, while its long-term counterpart is approximately 2.1. This suggests that an increase in Omani income by $1 \%$ results in an increase in Omani imports from S.K., by approximately $157 \%$ in the short term and by $210 \%$ in the long term.

The regression results for Thailand are given in Table 5. These results suggest that Omani income is strongly influenced by Omani oil exports to Thailand and to the rest of the world. The " $\mathrm{t}$ " value of the coefficient of the variable " $\mathrm{X}_{\mathrm{O}-\text {-Thailand,i }} \mathrm{t}$ ", which represents Omani exports to Thailand, is significant at the $5 \%$ level of significance. An examination of the coefficient $\left(\mathrm{Y}_{\mathrm{O}, \mathrm{t}-1}\right)$ further suggests the existence of a significant spread effects. 
Am. J. Applied Sci., 7 (4): 590-596, 2010

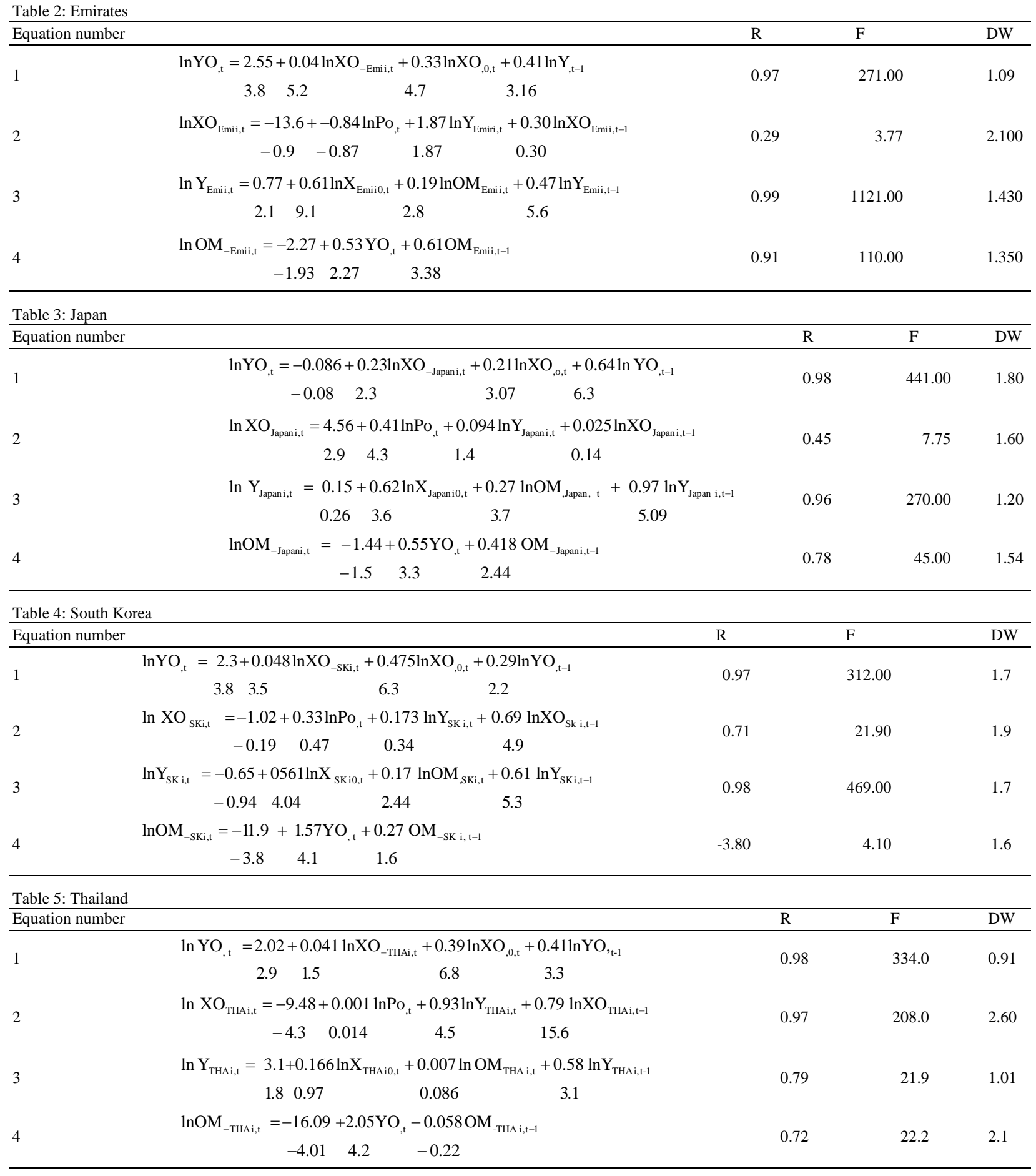

The results of the second equation suggest that Thailand's GDP and the lagged Xo variable is the major determinant of Omani exports to that Thailand while the price of oil does not have any significant impact on Omani exports to Thailand.
The coefficient $\lambda_{2}$ in the Thailand GDP function is not statistically significant, which suggests the absence of feedback effects. This is evident from the fact that the value of Omani imports from Thailand is quite a small proportion of Thailand's total exports (Fig. 1 and 2). 
Am. J. Applied Sci., 7 (4): 590-596, 2010

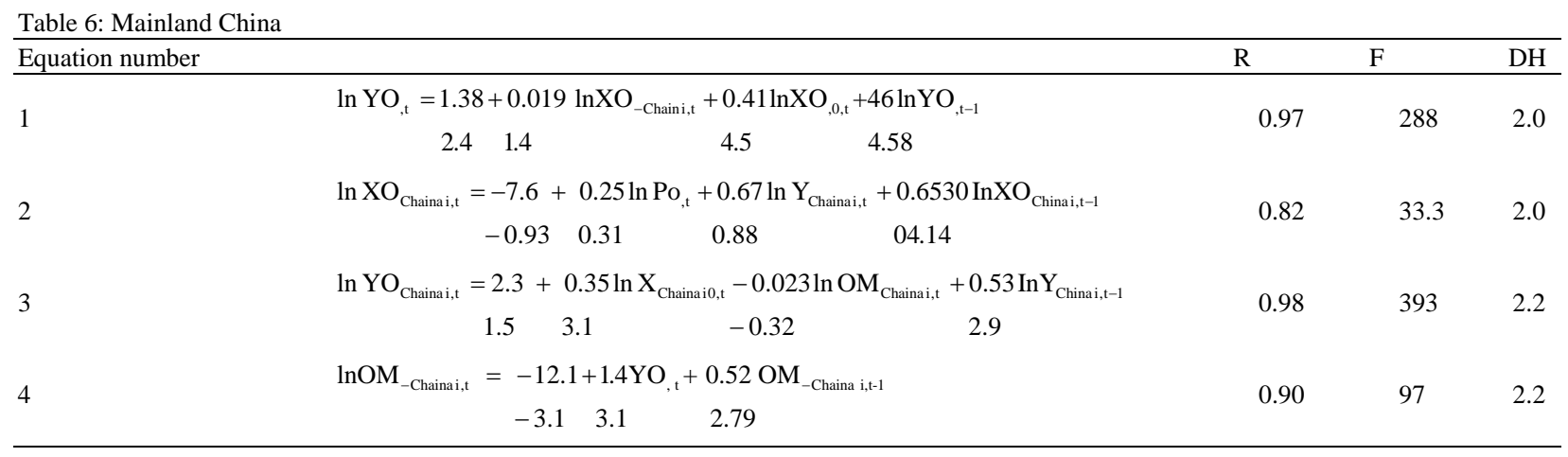

Although, the coefficient $\lambda_{3}$ in the Thailand GDP function is statistically significant at $5 \%$ level, which suggests the existence of a significant spread effects.

The regression results in the fourth equation suggest that Omani imports from Thailand are positively related to the Omani GDP. The marginal propensity of Omani imports from Thailand is approximately 0.77 but it is not significant in the long term. This suggests that an increase in Omani income by US $\$ 1$ results in an increase in Omani imports from Thailand by 77 US Cents in the short term.

The short-term elasticity of Omani imports from Thailand with respect to Omani income is approximately 2.0, while its long-term counterpart is approximately 1.9. This suggests that an increase in Omani income by $1 \%$ results in an increase in Omani imports from Thailand by approximately $200 \%$ in the short term. In contrast, the long-term elasticity of Omani imports is not statistically significant.

The regression results for China are given in Table 6. These results suggest that Omani income is slightly influenced by Omani oil exports to China and to the rest of the world. The " $\mathrm{t}$ " value of the coefficient of the variable " $\mathrm{X}_{\mathrm{O}-\mathrm{o}, \mathrm{i}} \mathrm{t}$ ", which represents Omani exports to countries other than China, is statistically significant at the $5 \%$ level of significance. An examination of the coefficient $\left(\mathrm{Y}_{\mathrm{O}, \mathrm{t}-1}\right)$ further suggests the existence of a significant spread effects. The results of the second equation suggest that the coefficient of $\mathrm{XO}_{\text {China i, t-1 }}$ variable is the key determinant of Omani exports to China while the price of oil does not have any significant impact on Omani exports to China.

The coefficient $\lambda_{2}$ in the China GDP function is not significant, which suggests the absence of feedback effects. This is evident from the fact that the value of Omani imports from China is a quite small proportion of China's total exports (Fig. 1 and 2). In contrast, the coefficient $\lambda_{3}$ in the China GDP function is statistically significant at a $5 \%$ level, which suggests the existence of a significant spread effects.
The regression results in the fourth equation suggest that Omani imports from China are positively related to the Omani GDP. The marginal propensity of Omani imports from China is approximately 0.5 in the short term and 1.05 in the long term. This suggests that an increase in Omani income by US\$1 results in an increase in Omani imports from China by 50 US\$ cent in the short term and 105 US cent in the long term.

The short-term elasticity of Omani imports from China with respect to Omani income is approximately 1.4, while its long-run counterpart is approximately 2.9. This suggests that an increase in Omani income by $1 \%$ results in an increase in Omani imports from China by approximately $140 \%$ in the short term and $290 \%$ in the long term.

\section{CONCLUSION}

This study was motivated by the need for an indepth empirical investigation examining the trade interdependence between Oman and its major trading Asian partners and to test if there are any feedback effects. A simultaneous equation model with double log equation form was developed and applied in order to identify the interdependence of trade between Oman and its major trading partners. The Two Stage Least Squares (2SLS) procedure was utilized in this study to carry out all estimations of the equations in the model and the main results can be summarized as follows:

- Omani GDP seems to be heavily affected by its export to its major trading partners in all cases except in the case of China. The coefficient of the lagged GDP variable of Oman is statistically significant at 5\% level in all cases which suggest the existence of a strong spread effects from the export sector to the rest of the Omani economy.

- The price of oil does not seem to be the major determinant of Omani exports to its major trading partners with exception of Japan. This could be explained by the fact that Omani economy depends 
so heavily on oil revenue; hence, it is necessary for Oman to continue exporting its oil independently of oil prices. In contrast, the GDP of Oman's trading partners is a major determinant of Omani exports to these partners.

- Oman imports from its major trading partners seem to have a significant impact (a feedback effect) on the level of GDP of its four major trading partners namely the Emirates, Japan and South Korea. Further, the short-term elasticity of Omani imports from its major trading partners with respect to its income seems to be higher (e.g., ranging from 0.55-2.0) in all cases except with the EU. This would suggest that Omani income has a strong impact on its imports from its major trading partners.

\section{ACKNOWLEDGMENT}

The earlier draft of this study was presented at The First International Conference on Applied Business and Economics-Oman at Crossroads: The Transformation of an Oil Economy, 30-31 March 2009 Sultanate Oman. The author would like to thank Mr. James Dahlstrom from Faculty of Arts at University of Wollongong for his constructive comments on the first draft of this study. Any errors in the study are the responsibility of the author.

\section{REFERENCES}

Ardakani, M.H., 1996. The role of oil exports in the economic development of Iran 1960-1992. University of Wollongong, pp: 398. http://ro.uow.edu.au/theses/1327/

Thirlwall, A.P., 1986. A general model of growth and development on Kaldorian lines, Oxford economic papers. New Ser., 38: 199-219.

Griffiths, W.E., R.C. Hill and G.G. Judge, 1993. Learning and Practicing Econometrics. 1st Edn. Johns Wiley and Sons, New York, ISBN: 0-47159951-4, pp: 866.
Gujarati, D., 2003. Basic Econometrics. 4th Edn., McGraw-Hill, New York, ISBN: 10: 0072427922, pp: 192.

Metwally, M.M. and R. Tamaschke, 2001. Trade relationship between the Gulf co-operation council and the European Union. Eur. Bus. Rev., 13: 292-296.

Metwally, M.M. and Y.R. Vadlamudi, 1992. Trade relationship between Australia middle eastern countries. Middle East Bus. Econ. Rev., 4: 13-22.

Metwally, M.M., F.A. Yahia and S.S. Ali, 2009. Trade relationship between Libya and its major trading partners. J. World Econ. Rev., 4: 55-72. http://www.serialspublications.com/journals1.asp?j id=388\&jtype $=$

Pindyck, R.S. and D.L. Rubinfeld, 1998. Econometric Models and Economic Forecasts. 2nd Edn., McGraw-Hill, Boston, ISBN: 0-07-050096-7, pp: 630.

Ramanathan, R.M., 1998. Introductory Economics with Applications. 4th Edn., Harcourt Brace College, New York, ISBN: 0-03-024616-4, pp: 664.

Rammadhan, M.A., 2000. The effects of the fluctuations in oil prices on the balance of payments of the GCC countries. University of Wollongong, $\quad 390$. http://ro.uow.edu.au/theses/1324/

Salvatore, D. and D. Reagle, 2002. Statistics and Econometrics. 2nd Edn., McGraw-Hill, New York, ISBN: 9780071348522, pp: 256.

Studenmund, A., 2000. Using Econometrics a Practical Guide. 5th Edn., Addison Wesley, Boston, ISBN: 0-321-31155-8, pp: 639.

Yahia, F.A. and M.M. Metwally, 2007. Impact of fluctuations in oil prices on investment in the Libyan economy. Global Rev. Bus. Econ. Res., 3: 1-12. http://www.serialspublications.com/journals1.asp?j id=199\&jtype $=1$ 